\title{
3D Printed Ultrahighly Sensitive Bioinspired Ionic Skin Based on Submicrometre-Scale Structures by Polymerization Shrinkage
}

\author{
Ling Cai ${ }^{1} \$$, Guangxue Chen ${ }^{1}+$, Junfei Tian ${ }^{1}$, Bin Su $^{2 *}$ and Minghui He ${ }^{1 *}$
}

${ }^{1}$ School of Light Industry and Engineering, South China University of Technology, Guangzhou, 510640, China

${ }^{2}$ State Key Laboratory of Material Processing and Die \& Mould Technology, School of Materials Science and Engineering, Huazhong University of Science and Technology, Wuhan, 430074 P.

R. China

Synthesis of polymerizable deep eutectic solvent (PDES). Choline chloride and acrylic acid were mixed at a molar ratio of 1:2, as shown in Figure S1, and heated in an oil bath at $90{ }^{\circ} \mathrm{C}$ for 50 minutes to obtain a transparent and uniform solution. FTIR and DSC were performed to determine the formation of polymerizable deep eutectic solvent (PDES). It can be seen from the FTIR (Figure S2) that the stretching vibration peak representing - $\mathrm{COOH}$ is still present at 1717 $\mathrm{cm}^{-1}$ of AA-CCl, indicating - $\mathrm{COOH}$ does not participate in the chemical reaction. The DSC curve (Figure S3) shows that the melting point $\left(\mathrm{T}_{\mathrm{m}}\right)$ of $\mathrm{AA}-\mathrm{CCl}$ is $-8^{\circ} \mathrm{C}$, which is lower than the melting point of acrylic acid (melting point $14^{\circ} \mathrm{C}$ ) and choline chloride (melting point $302^{\circ} \mathrm{C}$ ). Therefore, it can be confirmed that the PDES containing choline chloride and acrylic acid as components was successfully synthesized.

Preparation of 3D printed precursor solution. Since PDES has excellent mechanical, optical and electric properties, it can be used as a material for the 3D printing of bionic ion skin. First, the experiment explored the effect of different weight ratios of crosslinker on the mechanical properties and tensile testing was used to study the mechanical properties of 3D printed bioinspired ion skin. As shown in Figures S4 and S5, the tensile strain of the 3D printed bioinspired ion skin gradually deceases and the Young's modulus gradually increases as the content of the crosslinking agent increases. The 3D printed bionic ion skin with $0.1 \%$ crosslinker weight ratio shows a higher strain up to $\sim 175 \%$, whereas that with $10 \%$ exhibits a poor strain of $18 \%$. The Young's modulus values of the corresponding 3D printed bionic ion skin increase from 0.03 to $0.8 \mathrm{MPa}$. This 
demonstrates that the polymer networks have become close due to the contribution of a large dose of cross-linking agent, which also means that more external forces are required to move the molecular chain when the tight polymer network is mechanically deformed. In addition, the 3D printed bioinspired ion skin has the ability to transmit electrical signals without affecting its high transparency, which will greatly expand the range of its applications of it in various wearable flexible displays. On the basis of its properties and application, the printed bioinspired ion skin with $1 \%$ crosslinker/PDES weight ratio and exposure time of $5 \mathrm{~s} /$ layer was selected for the following experiments.

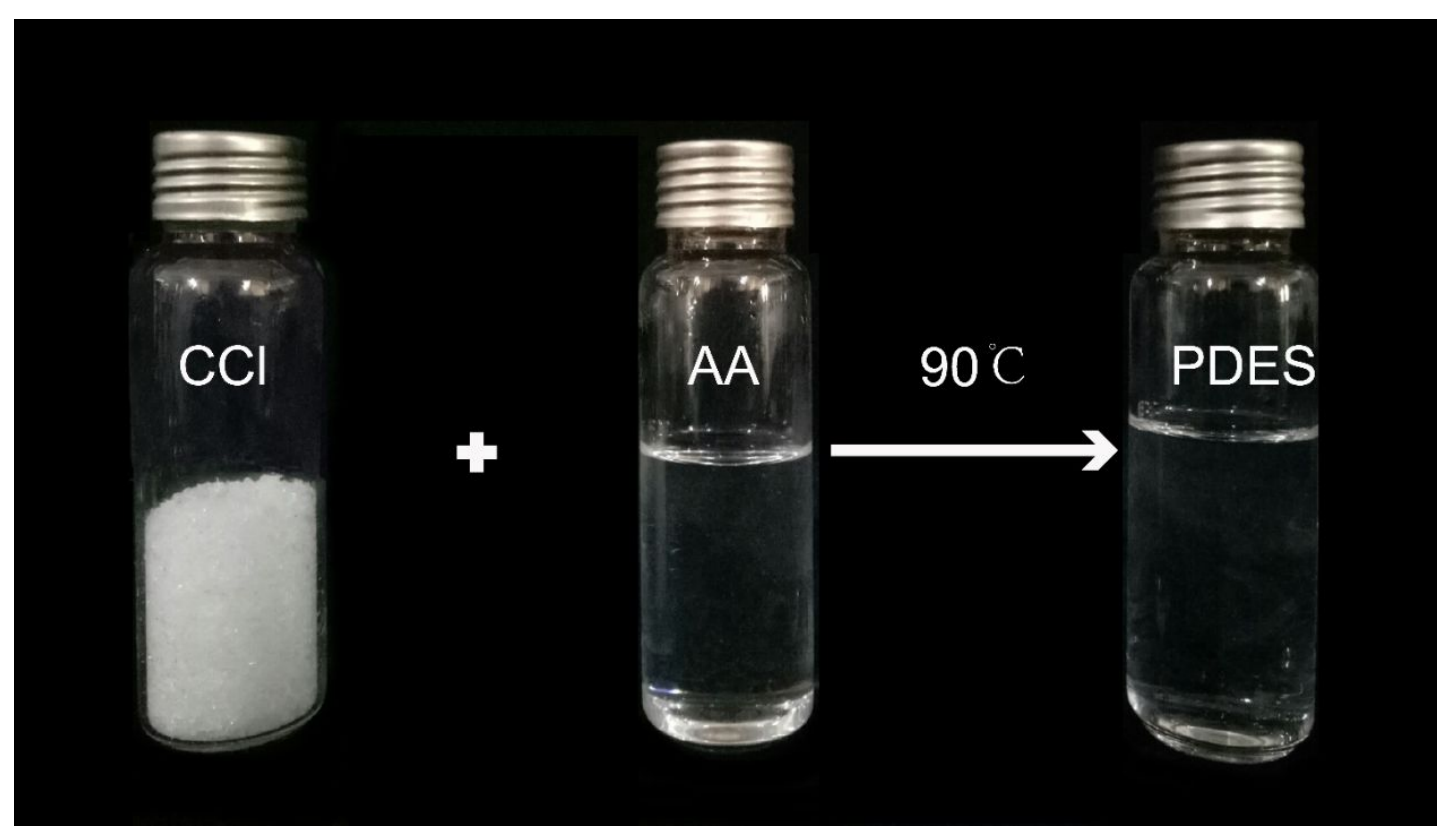

Figure S1. PDES synthesis demonstration with choline chloride and acrylic acid as components. 


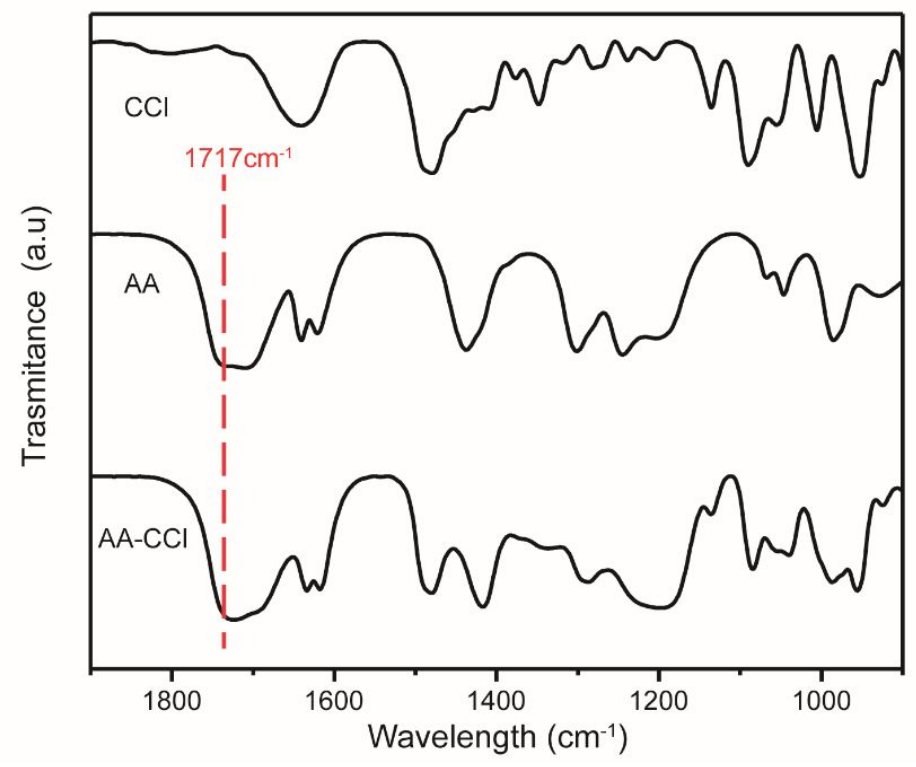

Figure S2. FTIR spectra of $\mathrm{CCl}$, AA and PDES.

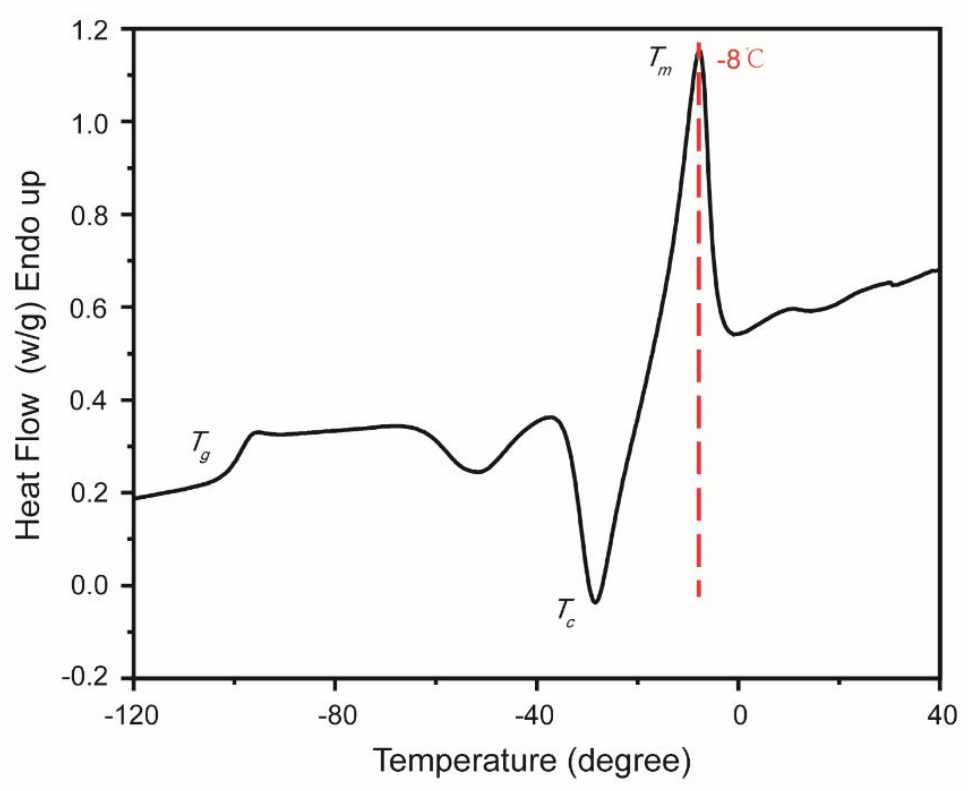

Figure S3. DSC curve of PDES. 


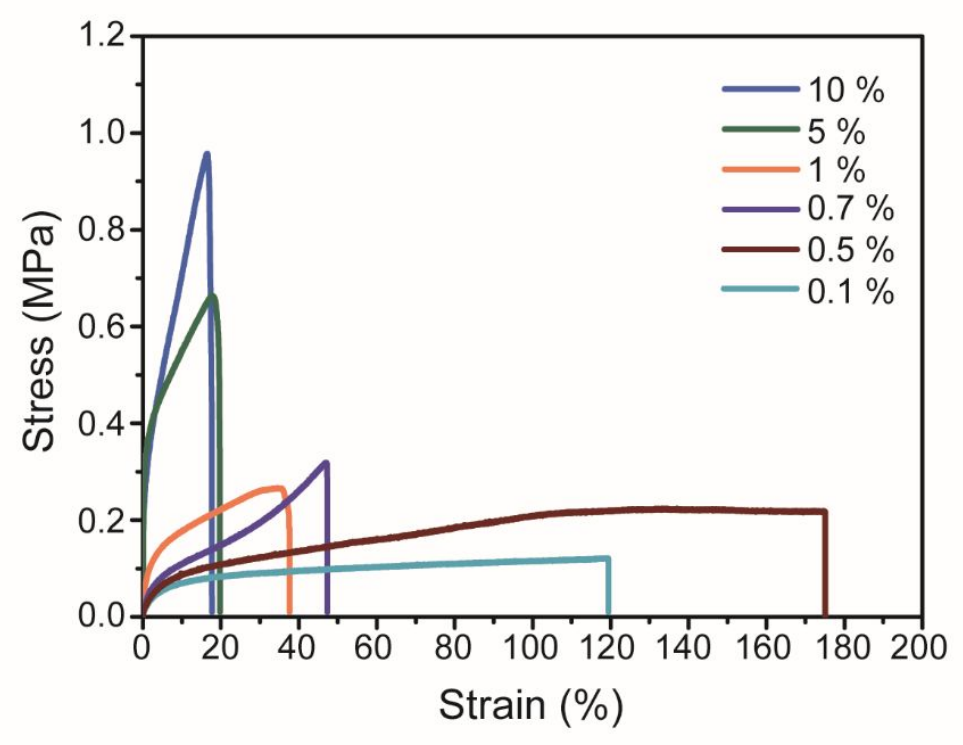

Figure S4. Stress and strain of bioinspired ion skin prepared with different amounts of crosslinker.

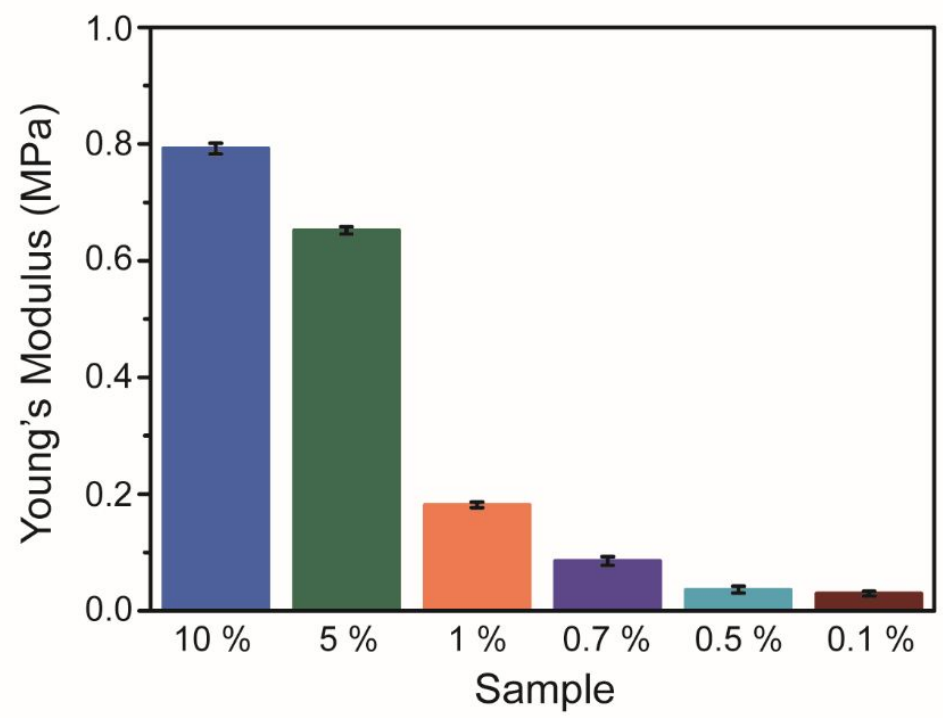

Figure S5. Young's modulus of bioinspired ion skin prepared with different amounts of crosslinker. 
(a)

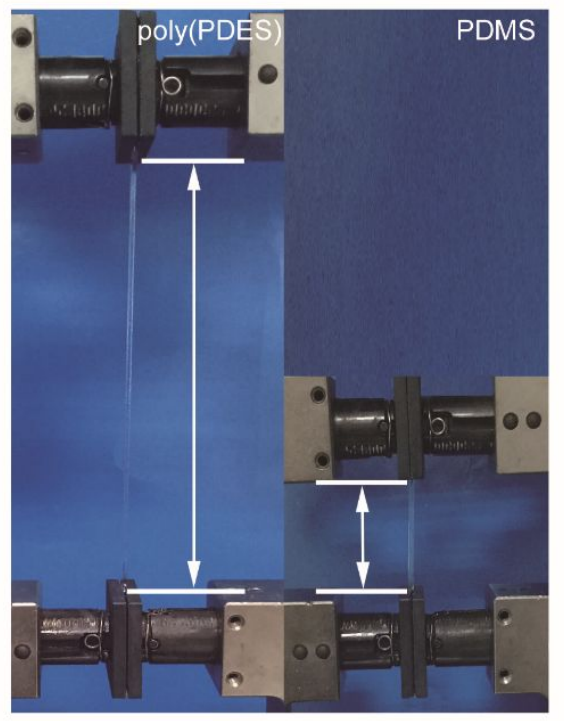

(b)

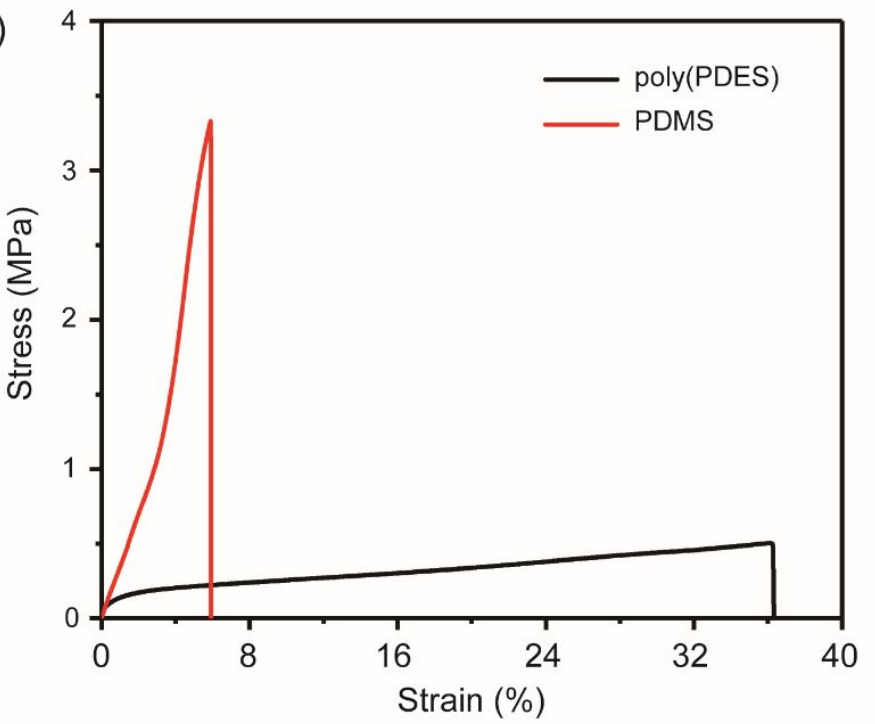

Figure S6. Stretch comparison of poly(PDES) and PDMS. (a) Optical image of stretch comparison of poly(PDES) and PDMS. (b) Fracture stretching of poly(PDES) and PDMS.

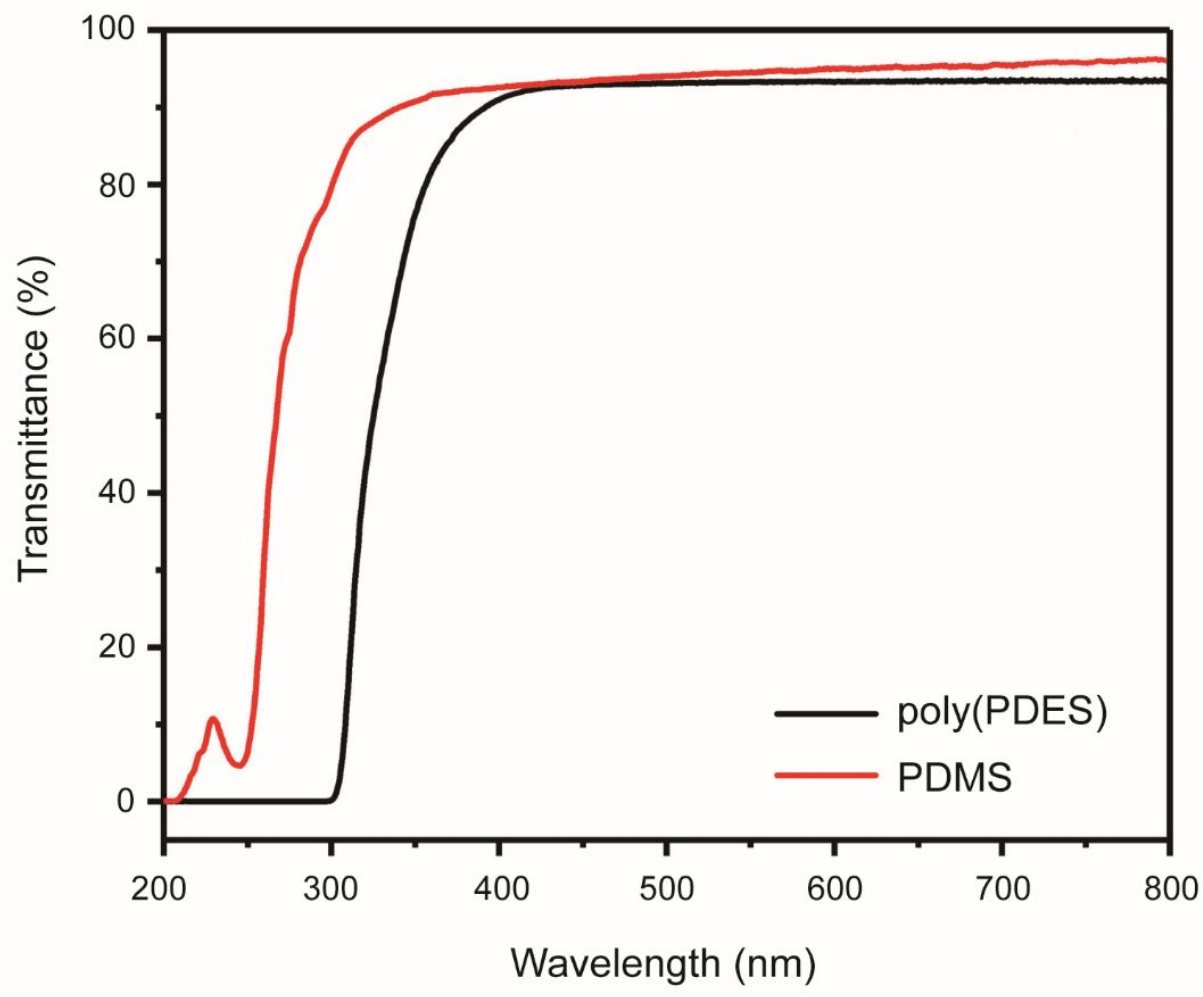

Figure S7. Comparison of transparency of poly(PDES) and PDMS. UV spectra of poly(PDES) and PDMS. 
(a)

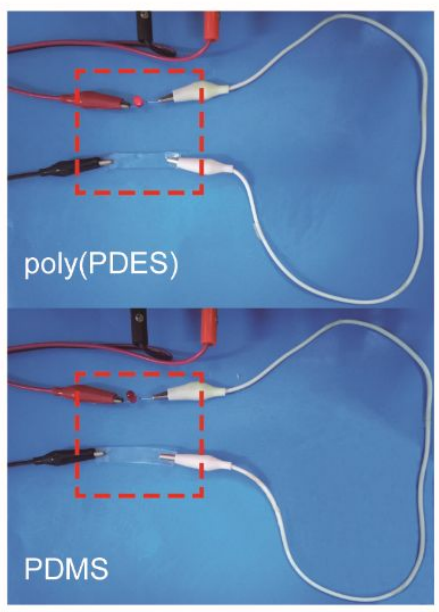

(b)

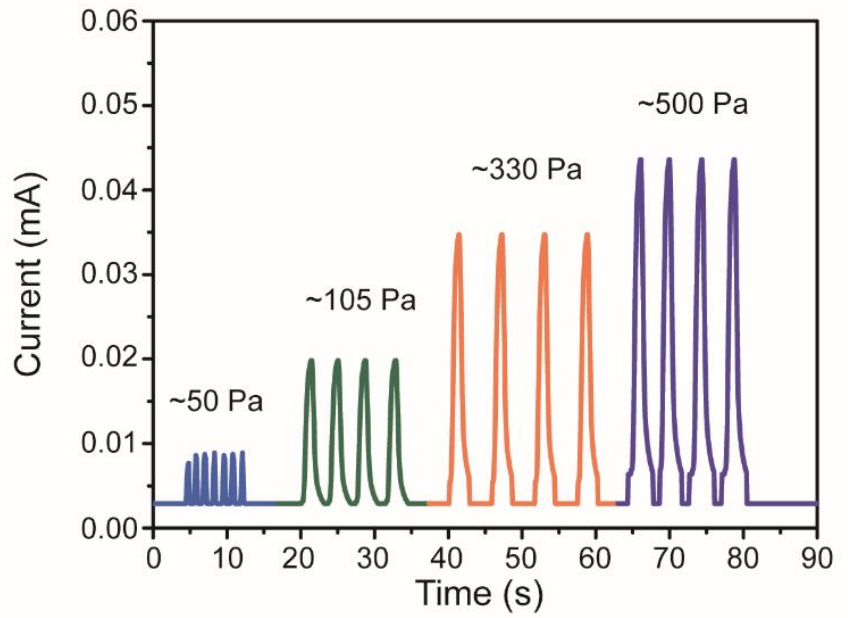

Figure S8. Conductive comparison of poly(PDES) and PDMS. (a) Optical image of conductive comparison of poly(PDES) and PDMS. (b) Current response of poly(PDES) under different pressures.

The conductivity of PDES at room environment is $0.453 \mathrm{~S} / \mathrm{m}$ and it has raised with the elevated temperature and humidity, as shown in Figures S9a, b. In addition, we also researched the conductivity of poly(PDES) polymerized by PDES. As shown in Figure S9c, the increase in temperature makes the conductivity of polymer improve exponentially since the rise in temperature greatly promotes the migration of conductive ions in the polymer. In $\mathrm{S} 9 \mathrm{~d}$, the raised humidity provides more conductive paths for conductive ions, so that the conductivity of the polymer ascends with the increased humidity. But the influence of humidity on conductivity is much smaller than that of temperature. 

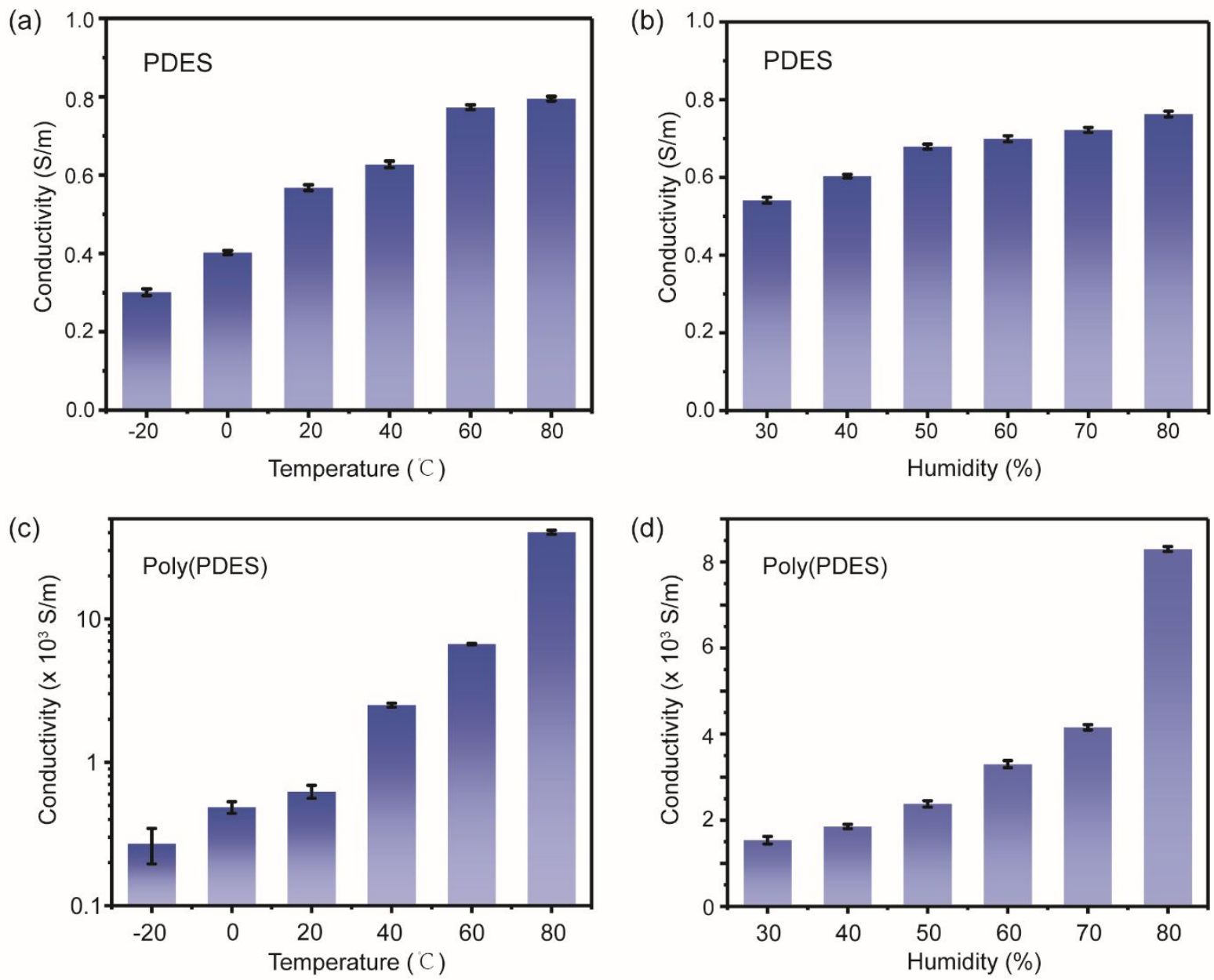

Figure S9. The conductivity of PDES and poly(PDES). (a)(b) The conductivity of PDES at different temperatures and humidity; (c) (d) The conductivity of poly(PDES) at different temperatures and humidity.

(a)

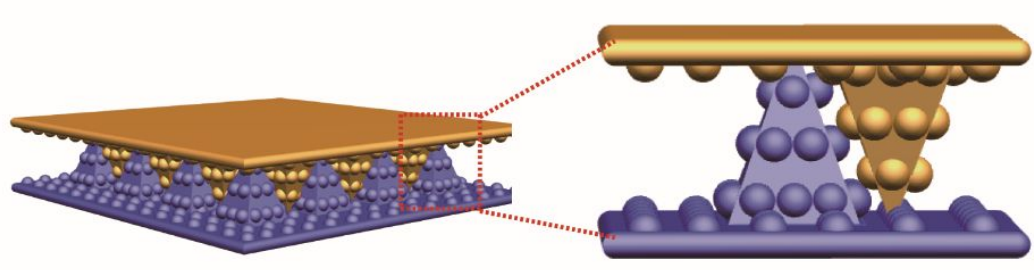

(c)

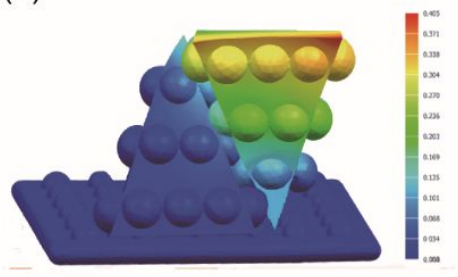

Figure S10. Finite element analysis of the basic unit of the bionic ion skin (BIS). (a) The threedimensional model of the BIS; (b) the sensing unit of the BIS; (c) the FEA of the basic unit of the BIS under static simulation. 
We illustrate the mechanism of submicrometric-scale structures affecting sensitivity by using the results of finite element simulation (FES). As shown in Figure S11a, when the pyramidal ion skin with no submicron structures is subjected to pressure, the force is mainly concentrated on the tip of the pyramid to cause corresponding deform, reflecting the changed color that appears in the result of FES. In S11b, we can observe that the existence of submicrometric-scale structures increases the area where the color changes in the FES, which means that the ion skin with submicrometric-scale structures will occur more deformation in the contact area and produce a greater resistance change compared with the ion skin without the submicrometric-scale structure. According to the sensitivity calculation formula (1), when the relative pressure is constant $(\delta \mathrm{P})$, the greater the relative resistance $\left(\delta\left(\Delta \mathrm{R} / \mathrm{R}_{0}\right)\right)$, the greater the sensitivity. It shows that the submicrometric-scale structures produce a larger relative resistance change by increasing the contact area and deformation when a force is applied, resulting in a higher sensitivity.

$$
\text { Sensitivity }=\delta\left(\Delta \mathrm{R} / \mathrm{R}_{0}\right) / \delta \mathrm{P}
$$

(a)

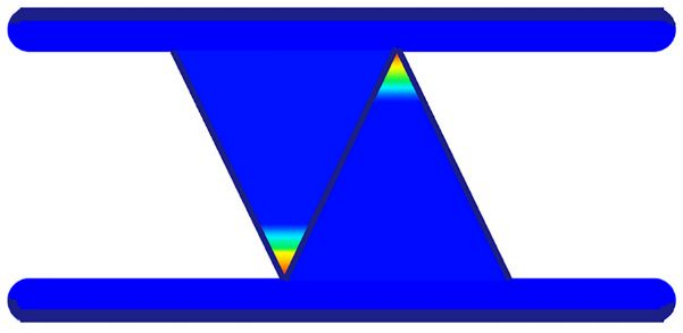

(b)

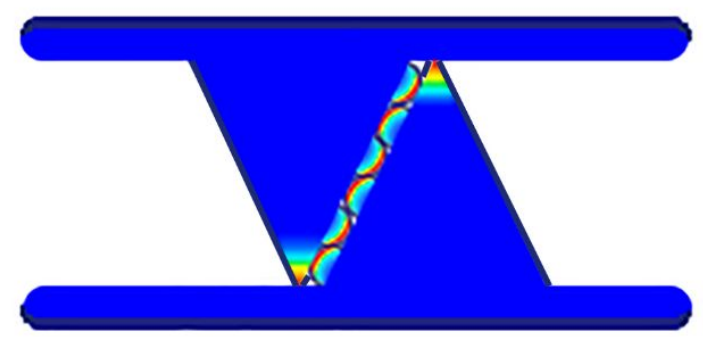

Figure S11. Finite element simulation results. (a) The pyramidal ion skin without the submicrometric-scale structures deforms its tip under force; (b) Simulation analysis of the bionic ion skin with submicrometric-scale structure under force. 


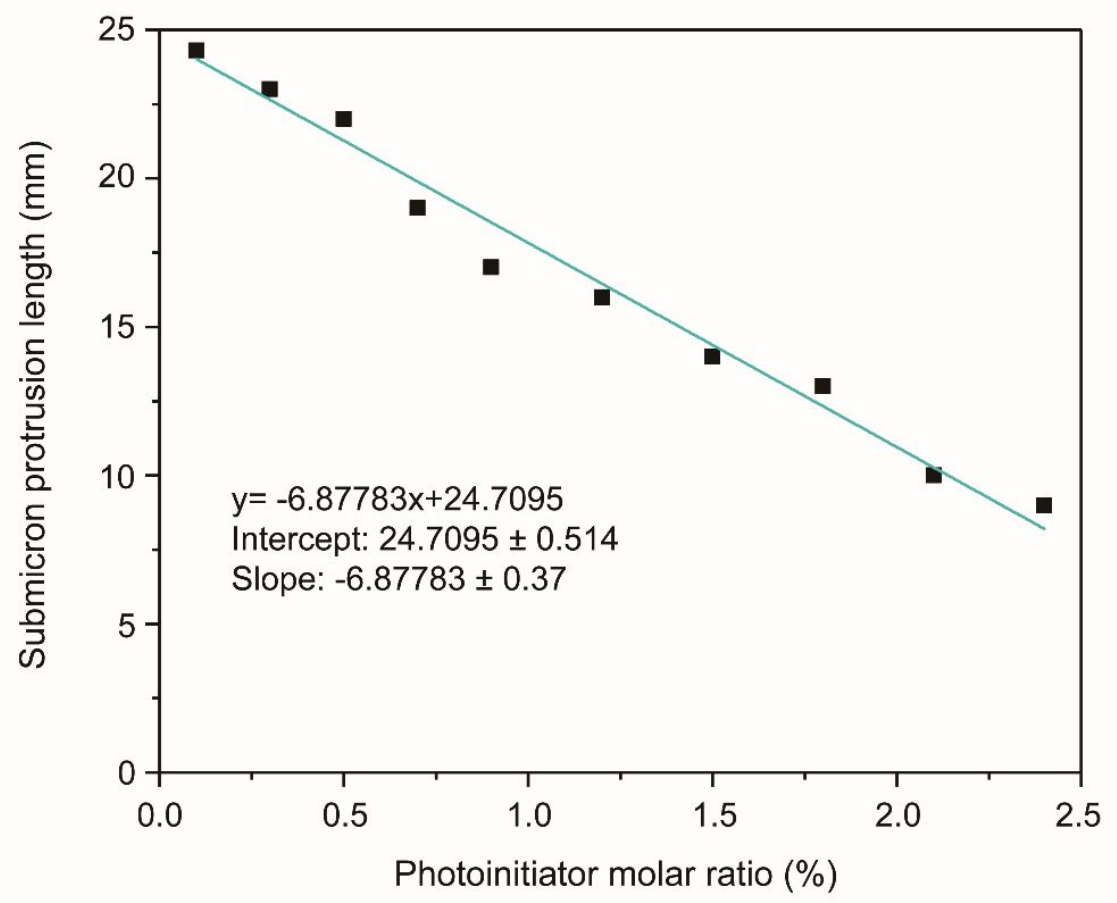

Figure S12 Fitting curve of point light source polymerization contraction.

In order to explore the factors that have the greatest impact on polymerization shrinkage in this experiment, we compared the effects of photoinitiators and crosslinkers on 3D printed PDES. We tested the double bond conversion rate of PDES containing different photoinitiator and crosslinker contents during the UV curing process. Figures S9-12 show that different contents of photoinitiators produce more differences in the double bond conversion rate under the experimental conditions of 5 s/layer. While the difference in the double bond conversion rate caused by different crosslinking agent contents is small under the same conditions. It can be concluded from this phenomenon that the photoinitiator has a greater influence on the polymerization rate and polymerization shrinkage effect of PDES. 

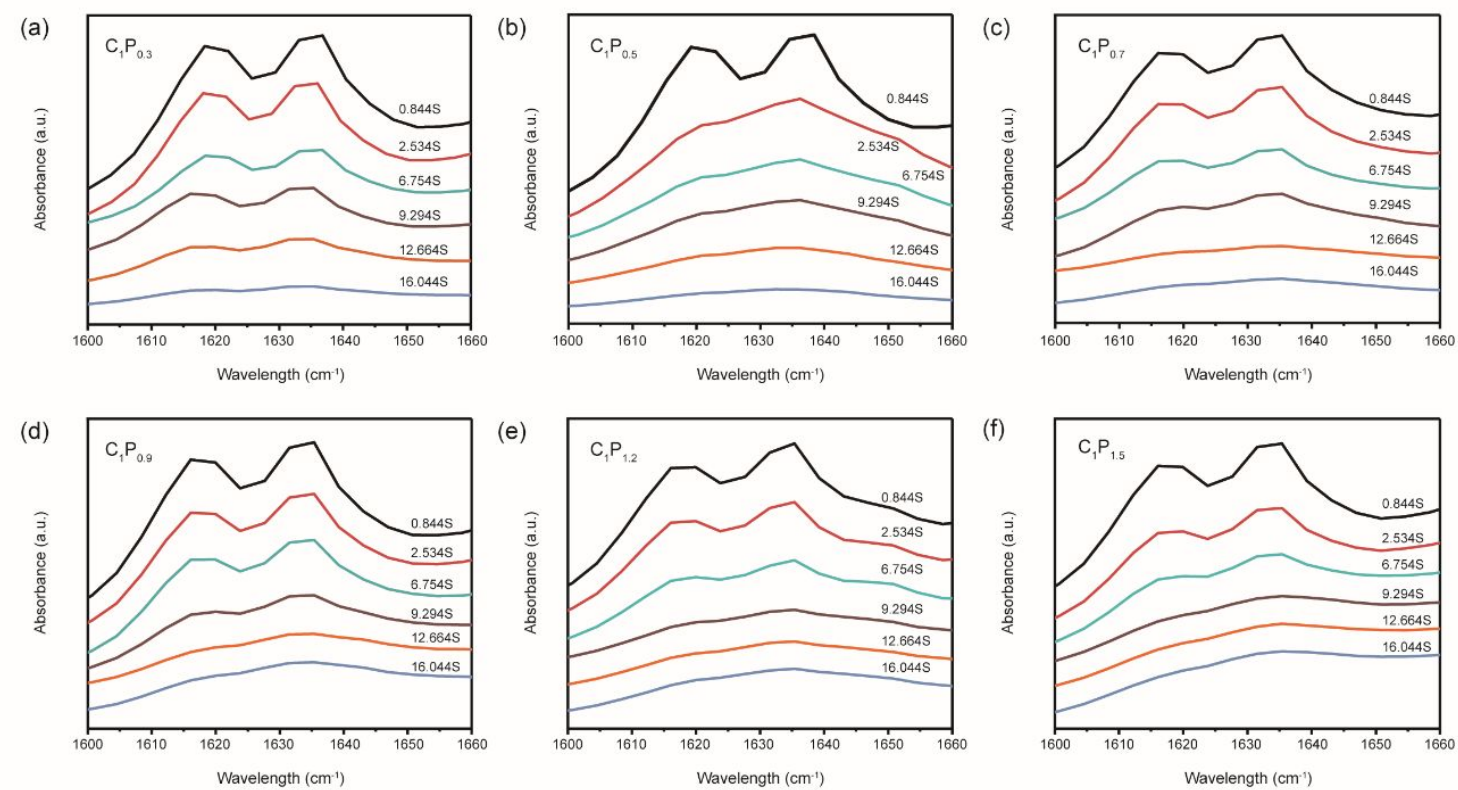

Figure S13. Double bond change process of PDES containing different proportions of photoinitiator during polymerization under real-time FTIR monitoring.

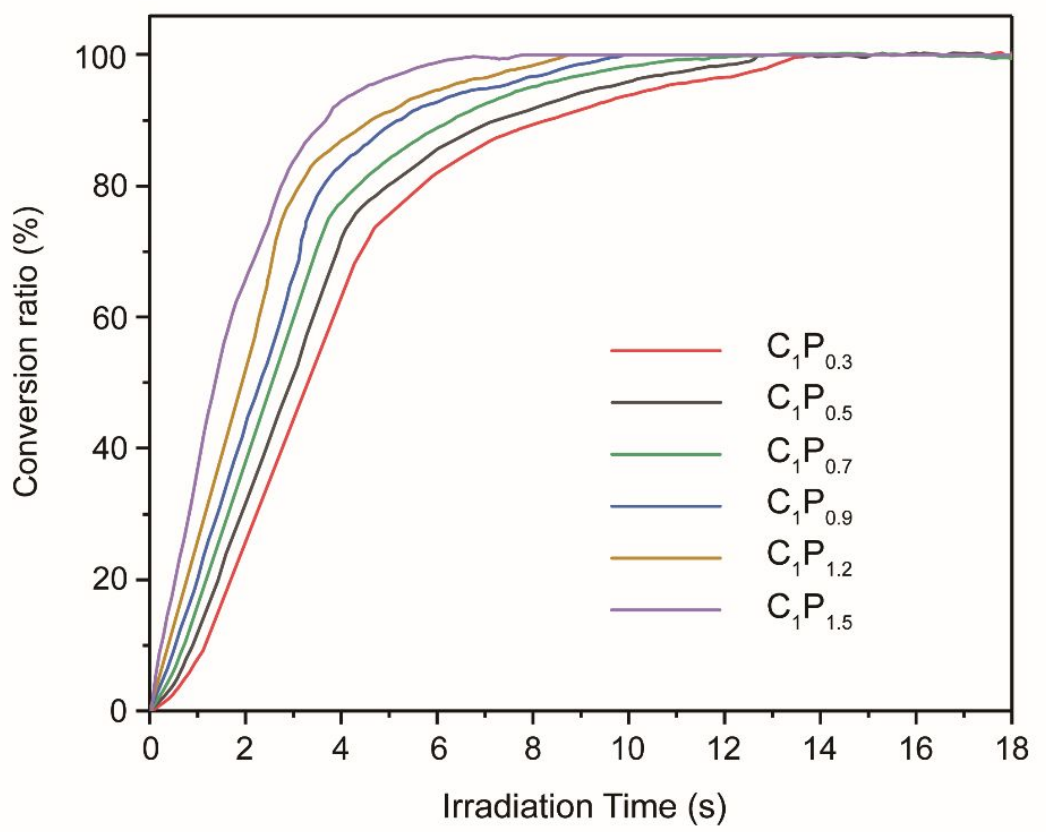

Figure S14. Double bond conversion rate of PDES with different photoinitiator contents during polymerization. 

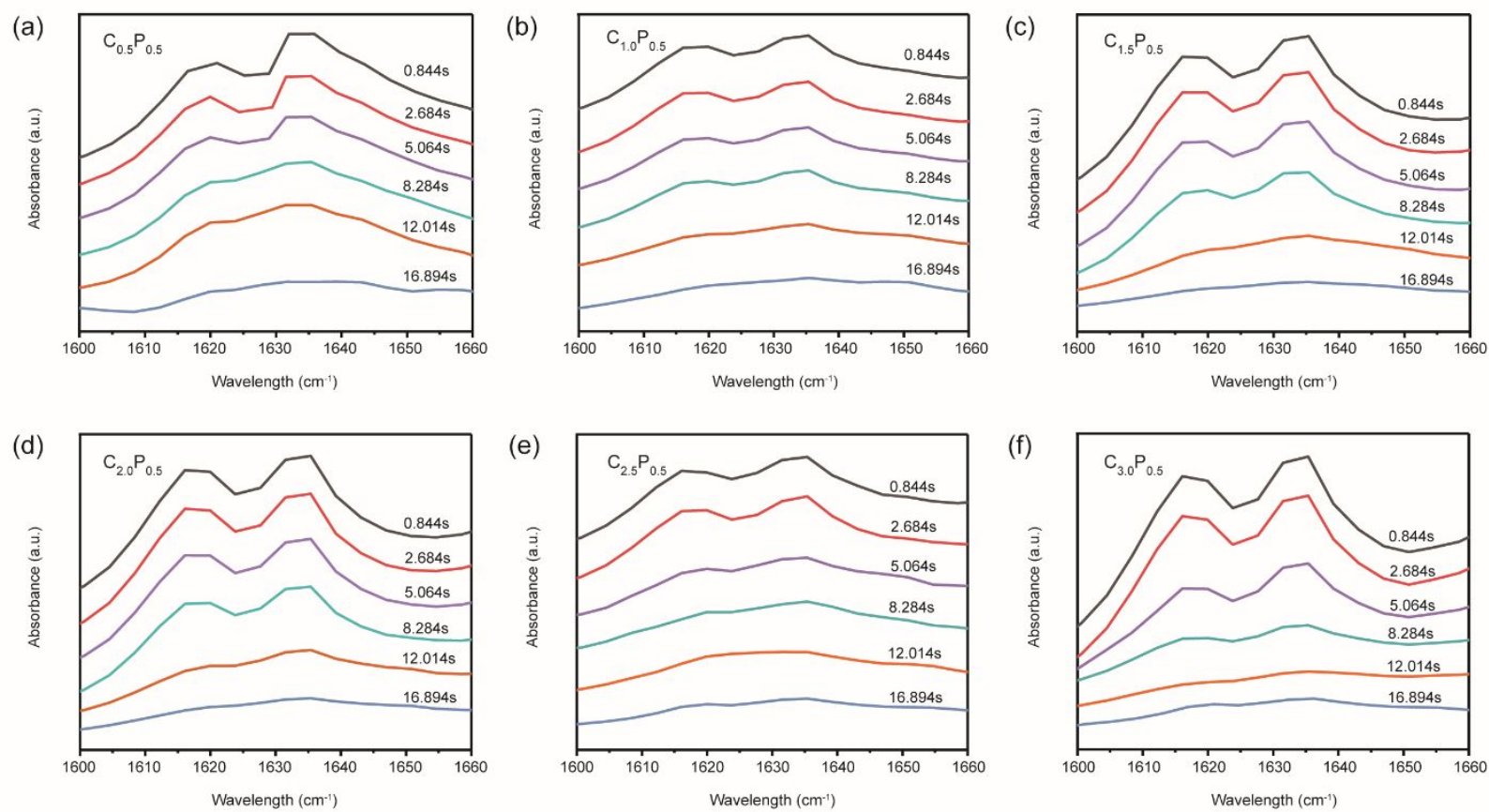

Figure S15. Double bond reaction process of PDES containing different proportions of crosslinking agent in real-time FTIR during polymerization.

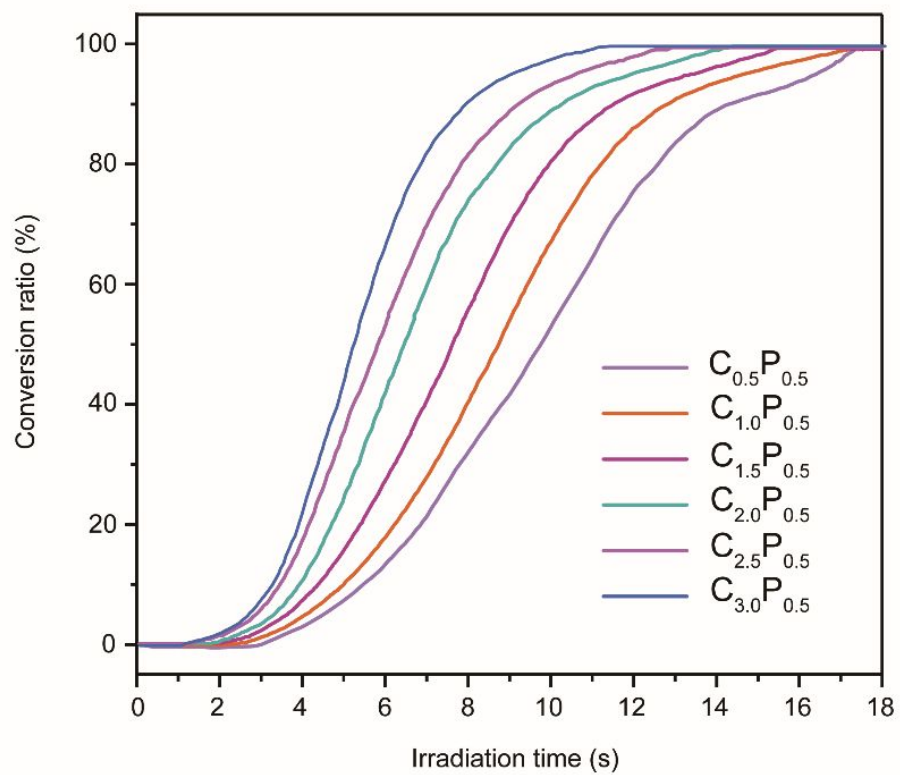

Figure S16. Double bond conversion rate of PDES with different crosslinking agents during polymerization. 


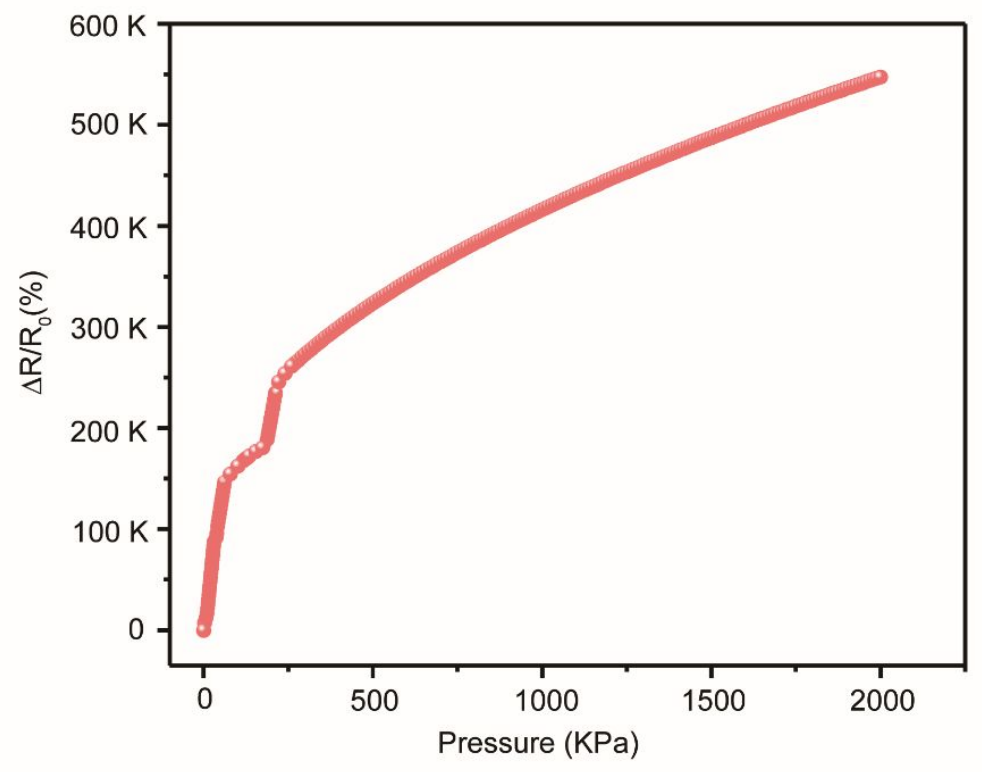

Figure S17. Whole pressure sensitivity of pyramidal-type bioinspired interlocked ion skin.

We have researched the influence of the different morphological features as well as dimensions on the sensing performance of the pyramidal bioinspired ion skin. Since the submicrometre-scale structures formed by polymerization and contraction under the lattice light source are all ellipses with different major axis sizes, we discussed the effect of submicrometre-scale structures with major axis lengths of $9 \mu \mathrm{m}, 18 \mu \mathrm{m}$ and $27 \mu \mathrm{m}$ on sensing performance. As shown in Figure S18a, when the length is $18 \mu \mathrm{m}$, the sensitivity is the highest, which is because the submicrometrescale structures of this size can just maximize the contact (the colored part of S18e is the deformation area ), so as to produce the largest relative resistance change under the action of external force. The corresponding response and relaxation time are also the fastest (S18b, c). While as the length is $9 \mu \mathrm{m}$, the structures cannot be completely contacted due to its small size (the colored part of S18d is the deformation area), resulting in insufficient deformation when external force is applied, which affects sensitivity. And when the length is $27 \mu \mathrm{m}$, only part of the contact changes when the external force acts because of the too large morphology (the S18f color part), leading the maximum sensitivity cannot be achieved. Insufficient contact also affects its ability to sense pressure, so its response and relaxation time is longer than that of fully contacted ion skin. 

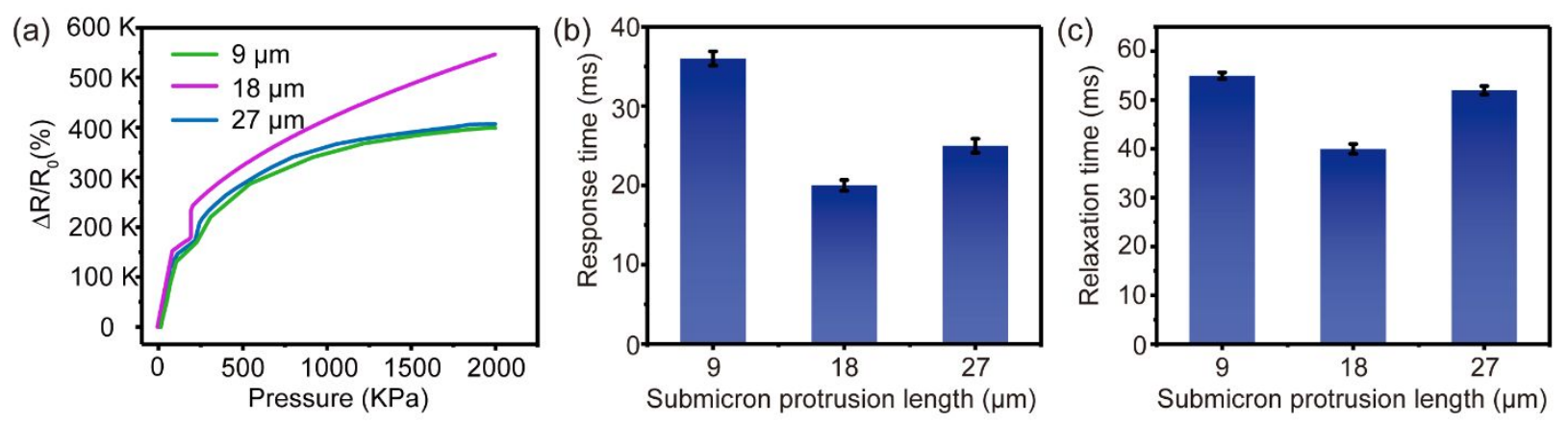

(d)

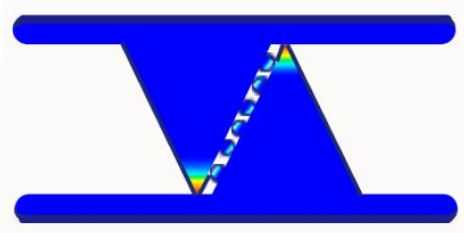

(e)

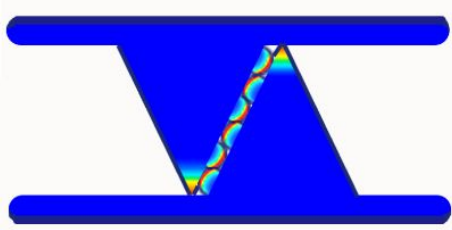

(f)

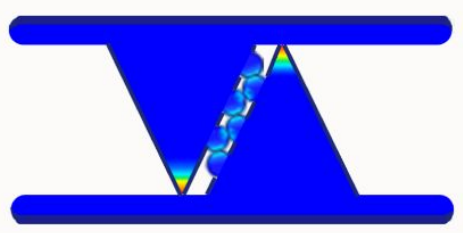

Figure S18. Comparison of sensing performance of different submicrometric size structures. (a) The sensing sensitivity of BIS when the submicron structure is $9 \mu \mathrm{m}, 18 \mu \mathrm{m}$ and $27 \mu \mathrm{m}$ (b) response times and (c) relaxation times. (d-f) Finite element static simulation of submicron structures of different sizes.

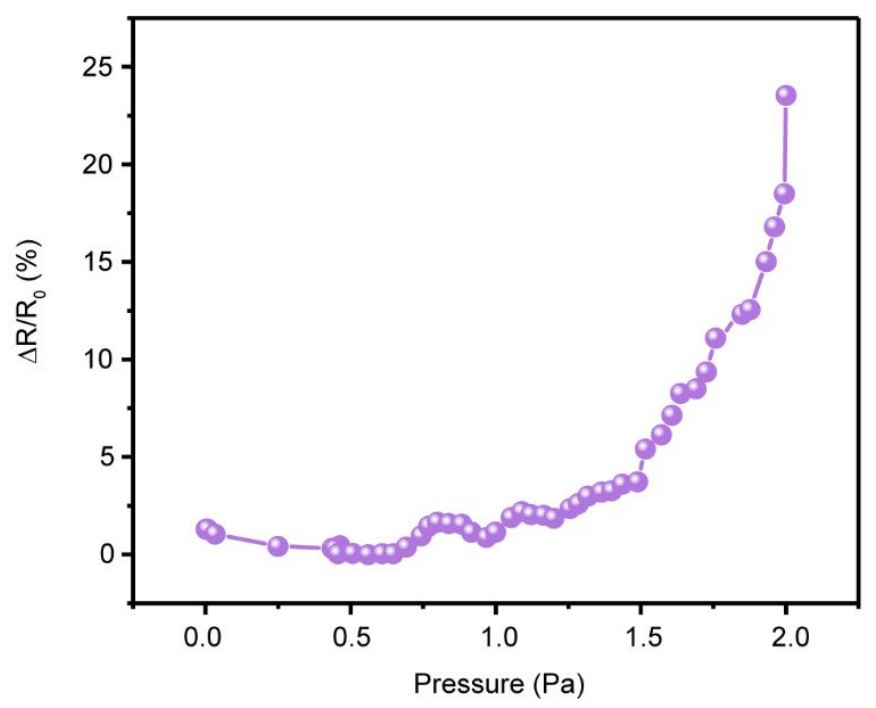

Figure S19. Minimum pressure which pyramidal bionic interlocked ion skin can sense. 

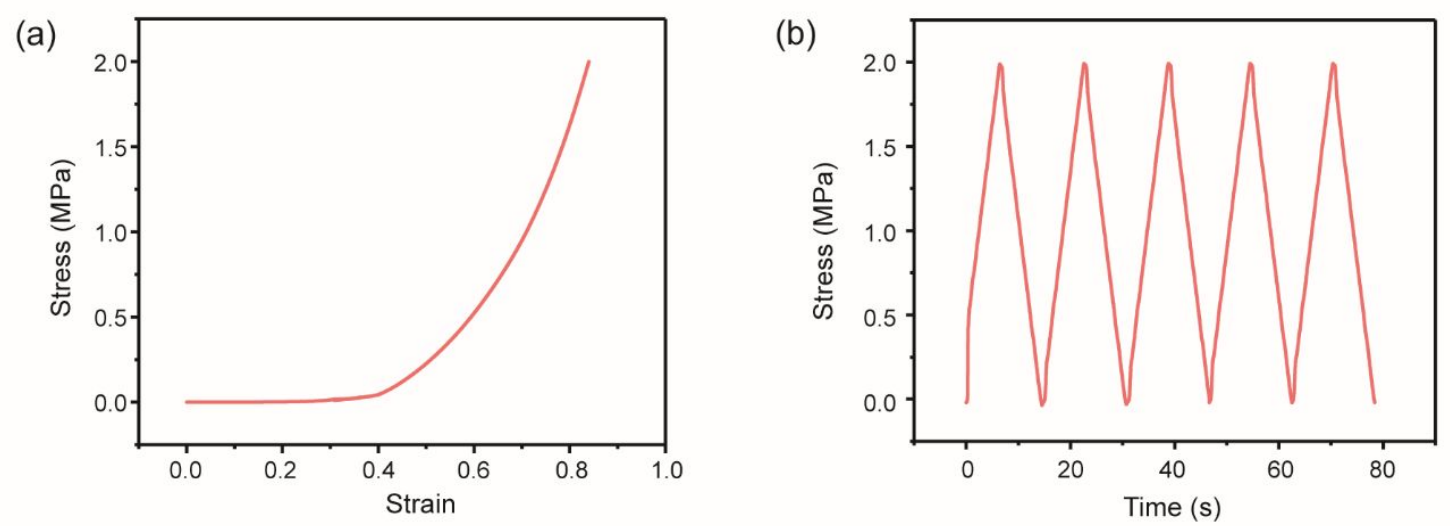

Figure S20. Maximum pressure which pyramidal bionic interlocked ion skin can sense. (a) Stable signal of pyramidal bionic interlocked ion skin sensing $2 \mathrm{MPa}$ pressure. (b) 5 cycles of ion skin under $2 \mathrm{MPa}$ pressure.

We monitor the pressure input signal and the output relative resistance change signal at the same time to confirm the hysteresis. As shown in Figure S21a, the input signal does not coincide with the output one completely, and the output electrical signal is significantly later than the input pressure signal, which confirms the hysteresis of the bioinspired ionic skin. This phenomenon may be mainly due to the viscoelastic nature of the poly(PDES). To further confirm the delay times, we can observe from Figure S21b that the delay times between the input and output signals is $0.02 \mathrm{~s}$, which is so short that can be ignored.
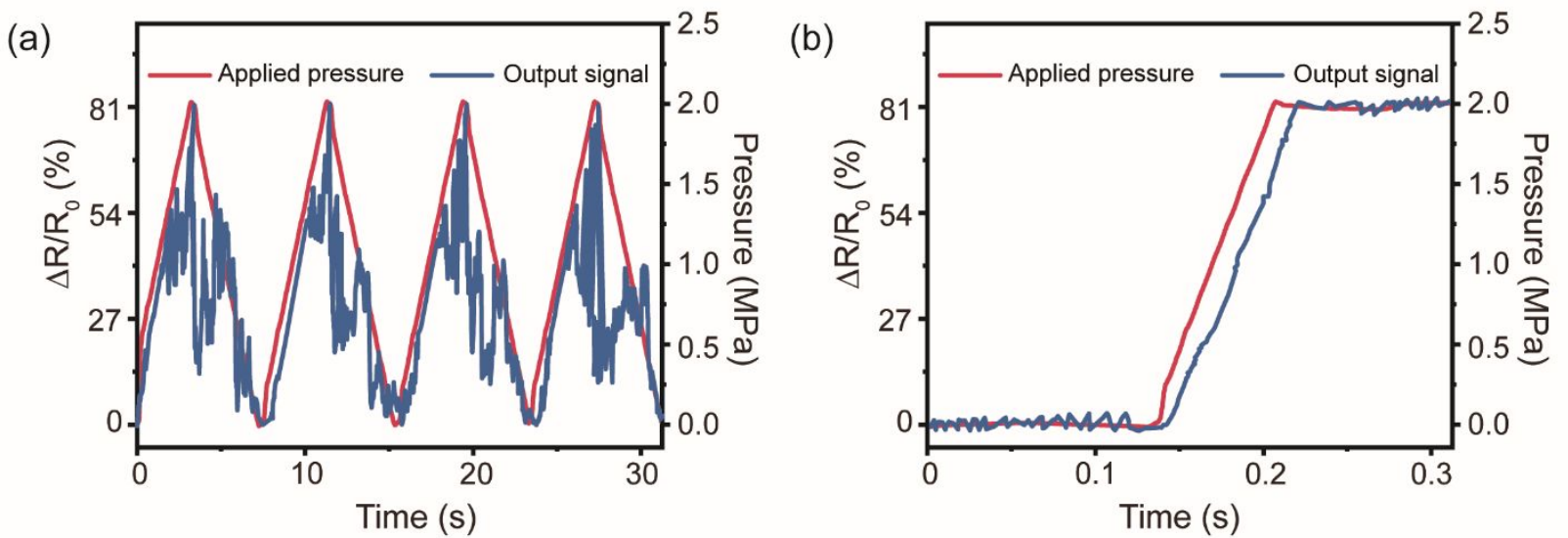

Figure S21. Hysteresis of bioinspired ionic skin. (a) The comparison between the input pressure signal and the output electrical signal; (b) The delay times between the input pressure signal and the output electrical signal. 
The pressure-strain curves of the bioinspired ionic skin that used as the pressure sensor. S22a displays that the pressure value is $2 \mathrm{MPa}$ when the compressive strain is $85.2 \%$. In $\mathrm{S} 22 \mathrm{~b}$, the pressure curves corresponding $10 \%, 30 \%, 50 \%, 70 \%$ and $85.2 \%$ compressive strain can be almost overlapped together, proving that it can return to the original height after each compression. Moreover, the pressure sensor still maintains $92.67 \%$ force and negligible residual strain even after 10,000 cycles (S22c).
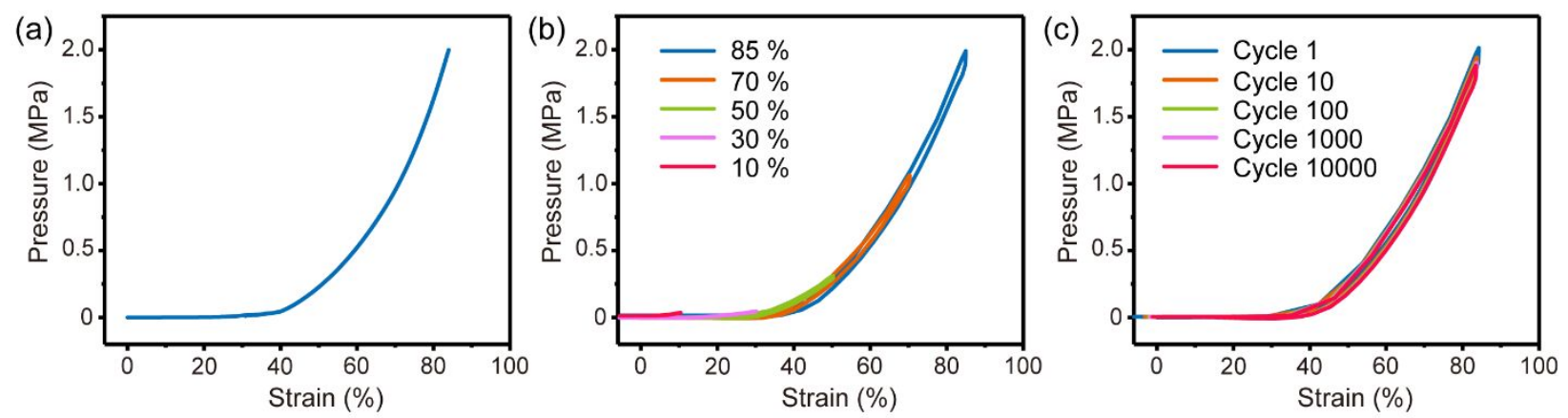

Figure S22. The pressure strain curve of the bioinspired ionic skin that used as a pressure sensor. (a) The maximum pressure-strain curve of the bioinspired ionic skin; (b) the pressure curve of the bioinspired ionic skin at different strains; (c) the pressure-strain curve of the bioinspired ionic skin at different cycles under maximum compression.

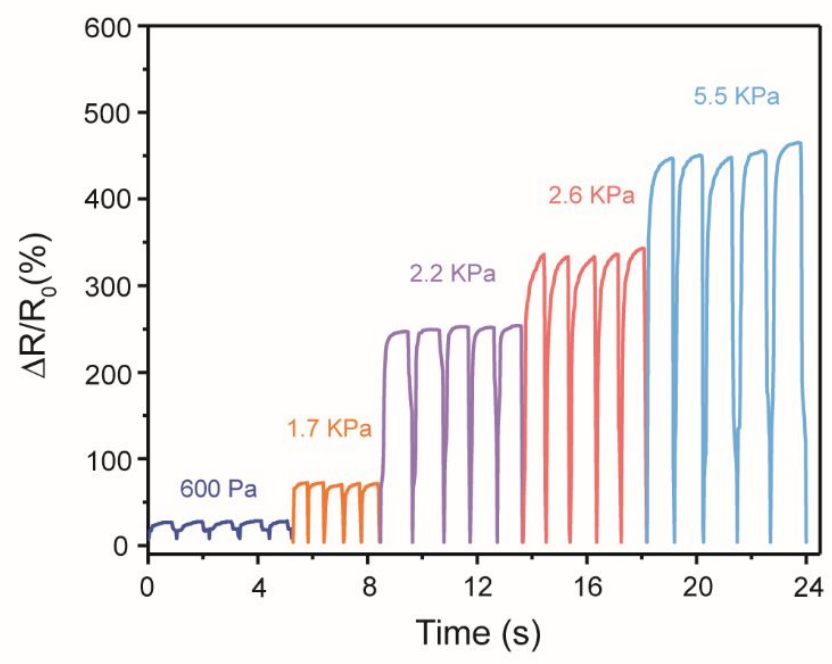

Figure S23. Relative resistance change of pyramidal bionic interlocked ion skin under different pressures. 


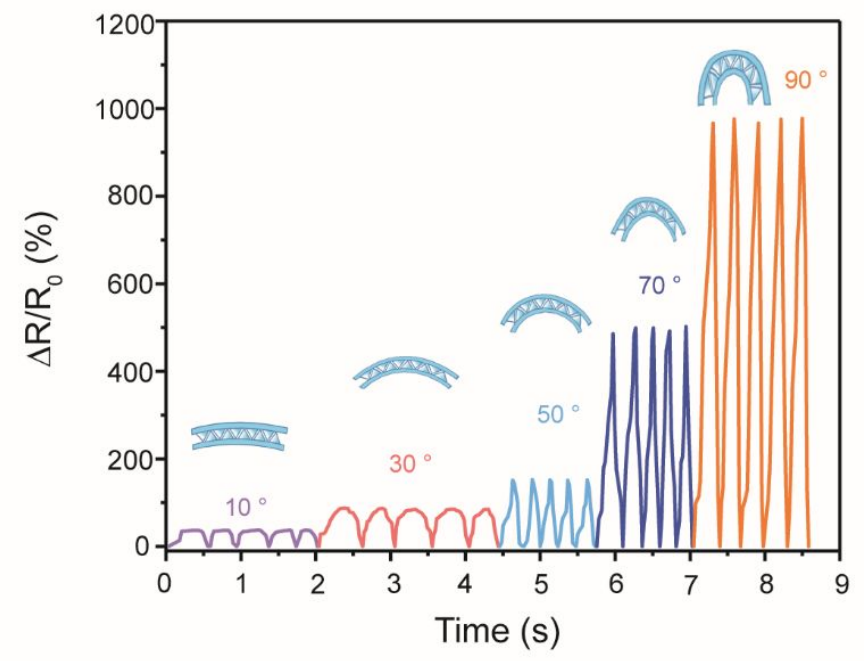

Figure S24. Relative resistance change of pyramidal bionic interlocked ion skin under different bending degrees.

(a)

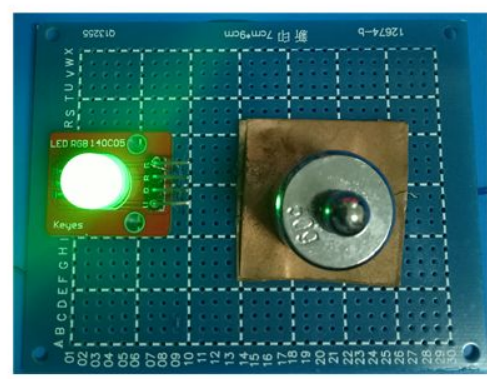

(b)

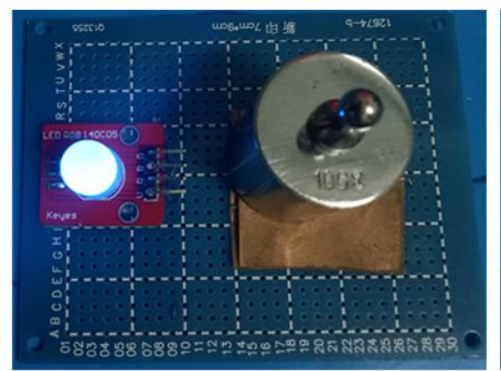

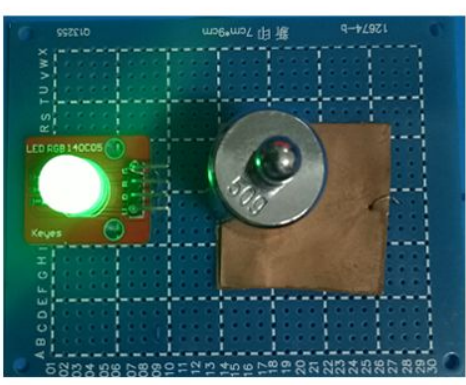
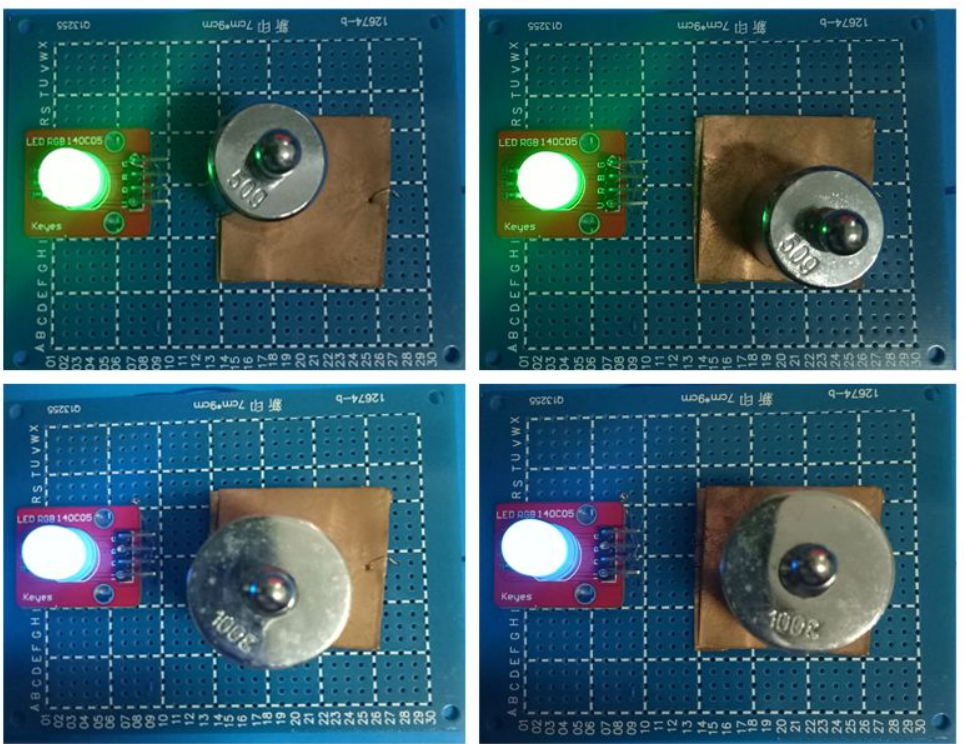

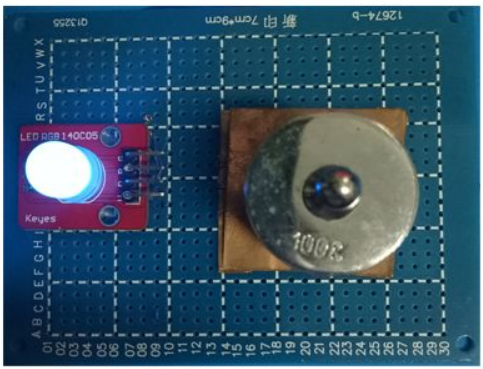

Figure S25. Stability test of visual inspection pressure sensor. (a) Optical images of 50g weight placed in different positions on pyramidal bionic interlocked ion skin. (b) Optical images of $100 \mathrm{~g}$ weight placed in different positions on ion skin. 


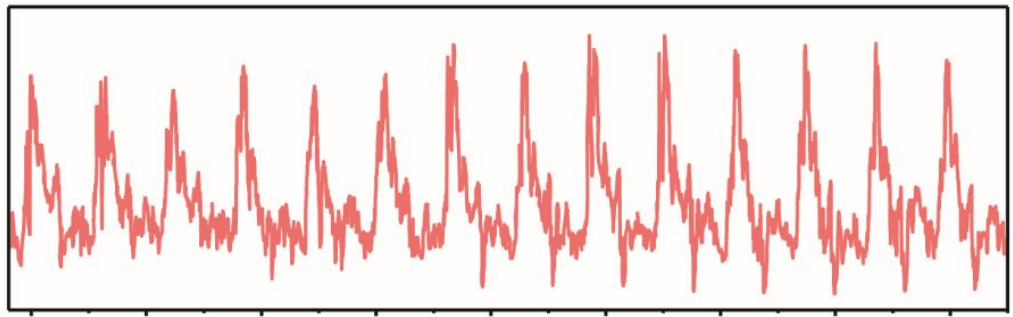

Figure S26. Electrical signals of human pulse beat measured by pyramidal-type bionic interlocked ion skin. 
Table R1. Comparison with reported visually detected pressure sensors

\begin{tabular}{|c|c|c|c|c|c|c|c|c|}
\hline Category & $\begin{array}{l}\text { Visuali } \\
\text { zation } \\
\text { mode }\end{array}$ & $\begin{array}{l}\text { Composite / } \\
\text { integrated } \\
\text { conductivity }\end{array}$ & $\begin{array}{l}\text { Sensi- } \\
\text {-tivity }\end{array}$ & $\begin{array}{l}\text { Press- } \\
\text {-ure } \\
\text { range }\end{array}$ & $\begin{array}{c}\text { Response } \\
\text { time }\end{array}$ & $\begin{array}{c}\text { Sensing } \\
\text { mechanism }\end{array}$ & $\begin{array}{c}\text { Transpar- } \\
\text {-ency }\end{array}$ & Ref \\
\hline Hydrogels & $\begin{array}{l}\text { Monoc } \\
\text { hrome } \\
\text { display }\end{array}$ & $\begin{array}{l}\text { integrated } \\
\text { conductivity }\end{array}$ & $\begin{array}{c}0.03 \\
\mathrm{kPa}^{-1} \\
(3.74 \\
\mathrm{kPa}) \\
0.003 \\
\mathrm{kPa}^{-1} \\
(3.74 \\
-12 \\
\mathrm{kPa})\end{array}$ & $\begin{array}{l}300 \mathrm{~Pa}- \\
12 \mathrm{kPa}\end{array}$ & $\begin{array}{c}10 \mathrm{~ms} \\
\text { (loading) } \\
12.5 \mathrm{~ms} \\
\text { (unloading) }\end{array}$ & $\begin{array}{c}\text { Resistive } \\
\text { conductive pressure } \\
\text { sensor }\end{array}$ & $99.80 \%$ & 1 \\
\hline Hydrogels & $\begin{array}{l}\text { Multi- } \\
\text { color } \\
\text { display }\end{array}$ & $\begin{array}{l}\text { Composite } \\
\text { conductivity }\end{array}$ & - & $\begin{array}{l}0-20 \\
\mathrm{KPa}\end{array}$ & - & $\begin{array}{c}\text { Resistive } \\
\text { conductive pressure } \\
\text { sensor }\end{array}$ & No & 2 \\
\hline Hydrogels & $\begin{array}{l}\text { Multi- } \\
\text { color } \\
\text { display }\end{array}$ & $\begin{array}{l}\text { integrated } \\
\text { conductivity }\end{array}$ & $\begin{array}{c}1.24 \\
\mathrm{kPa}^{-1} \\
(<150 \\
\mathrm{Pa})\end{array}$ & $\begin{array}{l}1.3 \mathrm{~Pa}- \\
6.53 \\
\mathrm{KPa}\end{array}$ & - & $\begin{array}{c}\text { Resistive } \\
\text { conductive pressure } \\
\text { sensor }\end{array}$ & No & 3 \\
\hline Ionic gels & $\begin{array}{l}\text { Three- } \\
\text { color } \\
\text { display }\end{array}$ & $\begin{array}{l}\text { Composite } \\
\text { conductivity }\end{array}$ & $\begin{array}{c}146.2 \\
\mathrm{kPa}^{-1} \\
(0- \\
1.3 \\
\mathrm{kPa}) \\
308.5 \\
\mathrm{kPa}^{-1} \\
(1.3- \\
4 \\
\mathrm{kPa})\end{array}$ & $\begin{array}{c}0.3-4 \\
\mathrm{KPa}\end{array}$ & $\begin{array}{c}272 \\
\text { ms(loading) } \\
234 \\
\text { ms(unloadi } \\
\text { ng) }\end{array}$ & $\begin{array}{c}\text { capacitive } \\
\text { ionotronic pressure } \\
\text { sensor }\end{array}$ & No & 4 \\
\hline $\begin{array}{l}\text { Composite } \\
\text { elastomer }\end{array}$ & $\begin{array}{l}\text { Monoc } \\
\text { hrome } \\
\text { display }\end{array}$ & $\begin{array}{l}\text { Composite } \\
\text { conductivity }\end{array}$ & $\begin{array}{c}0.66 \\
\text { and } \\
0.044\end{array}$ & $\begin{array}{c}0-100 \\
\mathrm{KPa}\end{array}$ & $20 \mathrm{~ms}$ & $\begin{array}{c}\text { capacitive } \\
\text { ionotronic pressure } \\
\text { sensor }\end{array}$ & $85 \%$ & 5 \\
\hline $\begin{array}{l}\text { Composite } \\
\text { elastomer }\end{array}$ & $\begin{array}{l}\text { Monoc } \\
\text { hrome } \\
\text { display }\end{array}$ & $\begin{array}{l}\text { Composite } \\
\text { conductivity }\end{array}$ & $1, \mathbf{n}_{-1}$ & $\begin{array}{l}20 \mathrm{KPa} \\
-2 \mathrm{MPa}\end{array}$ & - & $\begin{array}{c}\text { capacitive } \\
\text { ionotronic pressure } \\
\text { sensor } \\
\text { (Electroluminescenc } \\
\text { e) }\end{array}$ & No & 6 \\
\hline $\begin{array}{l}\text { Composite } \\
\text { elastomer }\end{array}$ & $\begin{array}{l}\text { Monoc } \\
\text { hrome } \\
\text { display }\end{array}$ & $\begin{array}{l}\text { integrated } \\
\text { conductivity }\end{array}$ & - & $\begin{array}{l}10 \mathrm{~Pa}- \\
250 \\
\mathrm{KPa}\end{array}$ & - & $\begin{array}{l}\text { Electromagnetic } \\
\text { pressure sensor }\end{array}$ & No & 7 \\
\hline $\begin{array}{l}\text { Composite } \\
\text { elastomer }\end{array}$ & $\begin{array}{l}\text { Double } \\
\text { and } \\
\text { transiti } \\
\text { onal }\end{array}$ & $\begin{array}{l}\text { Composite } \\
\text { conductivity }\end{array}$ & $\begin{array}{l}190 \\
\mathrm{kPa}^{-1}\end{array}$ & $\begin{array}{c}10 \\
\mathrm{KPa}- \\
2.4 \\
\mathrm{MPa}\end{array}$ & $10 \mathrm{~ms}$ & $\begin{array}{c}\text { capacitive } \\
\text { ionotronic pressure } \\
\text { sensor }\end{array}$ & $21 \%$ & 8 \\
\hline $\begin{array}{l}\text { Composite } \\
\text { elastomer }\end{array}$ & $\begin{array}{l}\text { Multi- } \\
\text { color } \\
\text { display }\end{array}$ & $\begin{array}{l}\text { Composite } \\
\text { conductivity }\end{array}$ & - & $\begin{array}{l}>2 \\
\mathrm{MPa}\end{array}$ & - & $\begin{array}{l}\text { Pressure-Sensitive } \\
\text { electrochemilumine } \\
\text { scence Sensor }\end{array}$ & $87.40 \%$ & 9 \\
\hline Our work & $\begin{array}{c}\text { full } \\
\text { spectru } \\
\mathrm{m} \\
\text { display }\end{array}$ & $\begin{array}{l}\text { integrated } \\
\text { conductivity }\end{array}$ & $\begin{array}{c}348.2 \\
8 \\
\mathrm{KPa}^{-1}\end{array}$ & $\begin{array}{c}0.6 \mathrm{~Pa}- \\
2 \mathrm{MPa}\end{array}$ & $20 \mathrm{~ms}$ & $\begin{array}{c}\text { Resistive } \\
\text { conductive pressure } \\
\text { sensor }\end{array}$ & $\sim 96 \%$ & - \\
\hline
\end{tabular}


References:

1 Chang, Q.; He, Y. F.; Liu, Y. Q.; Zhong, W.; Quan Wang, Q.; Lu, F.; Xing, M. Protein Gel's Phase Transition: Toward Superiorly Transparent and Hysteresis-Free Wearable Electronics. Adv. Funct. Mater. 2020, 30, 1910080.

2 Zhang, Z. H.; Chen, Z. Y.; Wang, Y.; Zhao, Y. J., Bioinspired conductive cellulose liquidcrystal hydrogels as multifunctional electrical skins. PNAS 2020, 31, 18310-18316.

3 Zhong, W. B.; Liu, Q. Z.; Wu, Y. Z.; Wang, Y. D.; Qing, X.; Li, M. F.; Liu, K.; Wang, W. W.; Wang, D. A nanofiber based artificial electronic skin with high pressure sensitivity and 3D conformability. Nanoscale 2016, 8, 12105-12112.

4 Keum, K.; Eom, J.; Lee, J. H.; Heo, J. S.; Park, S. K.; Kim, Y. H. Fully-integrated wearable pressure sensor array enabled by highly sensitive textile-based capacitive ionotronic devices. Nano Energy 2021, 79, 105479.

5 Zhang, Y. L.; Fang, Y. S.; Li, J.; Zhou, Q. H.; Xiao, Y. J.; Zhang, K.; Luo, B. B.; Zhou, J.; $\mathrm{Hu}, \mathrm{B}$. Dual-Mode Electronic Skin with Integrated Tactile Sensing and Visualized Injury Warning. ACS Appl Mater Interfaces 2017, 9, 37493-37500.

6 Zhao, X.; Zhang, Z.; Liao, Q. L.; Xun, X. C.; Gao, F. F.; Xu, L.X.; Kang, Z.; Zhang, Y. Self-powered user-interactive electronic skin for programmable touch operation platform. Sci. Adv. 2020, 6, eaba4294.

7 Ren, Z. W.; Nie, J. H.; Xu, L.; Jiang, T.; Chen, B. D.; Chen, X. Y.; Wang, Z. L. Directly Visualizing Tactile Perception and Ultrasensitive Tactile Sensors by Utilizing BodyEnhanced Induction of Ambient Electromagnetic Waves. Adv. Funct. Mater. 2018, 28, 1805277.

8 Su, L.; Jiang, Z. Y.; Tian, Z.; Wang, H. L.; Wang, H. J.; Zi, Y. L. Self-powered, ultrasensitive, and high-resolution visualized flexible pressure sensor based on colortunable triboelectrification-induced electroluminescence. Nano Energy 2021, 79, 105431.

9 Kwon, D. K.; Myoung, J. M., Wearable and Semitransparent Pressure-Sensitive LightEmitting Sensor Based on Electrochemiluminescence. ACS Nano 2020, 14, 8716-8723. 